アクションチェックリスト, 改善事例, 小グループ討論 を取り入れた現場参加型の職場改善トレーニングコース を中小企業に提供してきており, 労組, 安全衛生委員会, 経営者の自助努力によりユニークな改善活動を展開する 事業所が現れてきている.いくつかの改善活動から(1)中 小企業では安全衛生委員会が中心となり, 労働組合と経 営者が協力して職場改善活動を実施することが可能から 有効である(2)低コストで実現可能な改善の実施のために は現場労使のイニシアティヴによる職場巡視と小グルー プ活動が有効である(3)このように行われる改善活動は継 続的かつ多面的改善を期待できるとの結諭を得た.また， NPO による支援は(1)改善事例の紹介や産業医派遣など の技術支援(2)レーニングコースの開催によるファシリ テーターの養成(3)職場訪問による継続的改善の促進を行 っていくことが効果的である.

\section{5.中小企業における快適職場と KAIZEN}

岸田孝弥（高崎経済大学）

作業改善をする際のポイントは以下の 3 点である. (1) 作業現場で具体的に実現できる. (2)作業現場で働いてい る人の意見を聞く. (3)低コストで実現できる案を考兄出 す. 改善事例における問題点としてプラスチック工場で の具体例をあげると, (1)廃プラスチックを焼却し, その 熱を利用して温水にし，それをもとに床暖房を実施しょ うとしたところ, 焼却炬の設置が工場の建物に近すぎて, 消防署から移設するように注意を受けた，(2)女子のパー トタイマーが製品収納用の段ボールを倉庫の棚から降ろ す際に，重量物となるために腰への負担が大きかった。 そのため, 床ごと上下するリフトを作製して対応した。 この時は労働基準監督に事前に相談しておいたのでトラ ブルもなく許可が抢りた。このように改善の際に，監督 署との事前の打ち合わせをして扔かないと, せっかく改 善しても, 法的に許可が下りないなどのトラブルに巻き 込まれる，中小企業ではよくあることなので注意を要す る.

\section{6.『小規模』弁当工場における安全衛生取り組みの第 一歩}

天明佳臣 ${ }^{1}$, 西田隆重 ${ }^{2}, \bigcirc$ 川本浩之 ${ }^{2}$

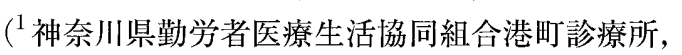

2 神奈川労災職業病センター)

$\mathrm{Y}$ 市内の仕出し弁当業社 $\mathrm{A}$ 食品において, 同社の労 働組合副委員長 B 氏の腰痛問題をきっかけにして, 職 場改善の取り組みを試みた。激しい競争を背景に，短時 間労働者の割合も高く, 定着率も低い職場であるが, B 氏をはじめとする労働組合メンバーは少しでもいい職場 を作ろうと努力している．腰痛アンケートを実施して， B氏だけの問題ではないことも確認した。また，B氏が
工場長的な存在であることなどから，Y工場の見学が実 現, 調理, 盛り付け, 配送, 洗浄各部門において, 問題 点を把握することができた．限られた条件の中でもいく つか改善できる点があることもわかった.

それらの結果を実質上の経営者である専務に面談して 伝えた。また，社員としての自覚，職場へのこだわりを 従業員に持ってもらうことを目的に，名札の着用を提言 したが，実現には至っていない。今後も粘り強い取り組 みが必要である。

\section{7. 茨城産業保健推進センターの活動状況と展望}

村上正孝（茨城産業保健推進センター）

開所 4 年目, 健康環境作業管理, 講師依頼 - 機器貸出, 法令解釈，精神保健等の相談件数年間 800 件. そのうち 食料品製造 (騒音, 排水), 分析セン夕 (安全管理体 制・活動), 研究所（精神保健体制, 相談方法）など多 様な業種と課題に継続的実地相談指導を実施中. 一方, 呼吸保護具, 精神保健ネットワーク, 事業主の健康管理 意識などの調查を行い問題点を明示して事業主の取組み を喚起した．所内外セミナーは年間 100 回を超す.

今後の事業展開の鍵；1. 相談事業の頻度と内容の哚 化のために（1）行政による紹介事業所への相談指導の 増加，(2) 自主的問題解決を促す OHS-MS 普及セミナ 一の企面，（3）中小企業事業組合の問題解決支援（美容 業の接触皮虐炎等)，(4) 労働組合の利用促進，（5）職 業性疾病の鑑別診断助言. 2. 研修事業の充実のために 研修内容の高度化と利用者のニーズに適合した内容を提 供する。

\section{8. 新宿地域産業保健センター事業の利用者の特徵}

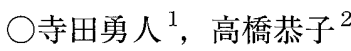

( ${ }^{1}$ 東京都杉並区高円寺保健センター,

2 新宿地域産業保健センター)

新宿地域産業保健センター事業の 1996〜 1999 年度, 過去 4 年間の利用者の特徴を分析した. 利用企業は 102 事業場, 延べ利用者数 280 人, 延べ相談内容 358 件であ った．利用のきっかけは労働基準監督署からの紹介が約 半数で, その他センターが普及啓発を行った様々な関係 機関からの紹介があった．また，センター側からアプロ 一チしたところが 2 割存在した。利用者の役職は，「労 務担当者等」 103 人, 「役員 - 管理者等」 89 人と多く, 「労働者」は 9 人であった. 1999 年度に入って新たな利 用者として「産業医」があり，地域の開業医にもセン夕 一の存在と機能が徐々に浸透したことが伺えた。利用内 容は「産業医」や「管理体制全般」に関することが多く， 同一事業揚の利用回数は，24回を最多に 2 回以上利用 したリピーターは約 6 割であった今後より一層地域の関 係機関と連携協力を密に，センター側から積極的に活動 